Redhead, $21.3 \% \quad(80$ from 375 birds banded).

Mallard, $21.2 \%$. (413 recoveries from 1946 birds banded).

Pintail, $13.7 \%$ (69 recoveries from 504 birds bandied).

Blue-winged Teal, $4.9 \%$ (65 recoveries from 1335 birds banded).

Remember that these figures need to be approximately doubled to give the true loss from hunting; to allow for orippling losses; unrecovered birds and bands not reported. Thus Canvasbacks and Redheads are subject to about $40 \%$ mortality from shooting each year.

Most of this shooting is done in the United States, so they will need to reduce their bag limits for diving ducks. In Canadia, game regulations must also take the diving ducks into account. In Manitoba, they open the duck season in two sections-an early opening for stubble shooting, to help reduce crop depredations by the Mallards and Pintails; and a later opening of over-water marsh shooting, to protect the diving ducks. I would suggest the last week in August and the first week in October as being suitable dates for Saskatchewan. There are theoretical difficulties in enfoncement, but these are not much more serious than supervising before-season permits for crop protection or having waterfowl and upland game seasons opening on different dates. If a hunter has five Canvasbacks and three Redheads in his bag, he wasn't shooting over stubble!

There is an urgent need to educate the public to the value of our marshlands; as our population grows, we need the marshes more, not less. Let us nat be misled by the cry that "we must not oppose progress." Socalled progress may be in a backward direction! Even from an economic aspect, marshes rarely become good farm land and the value to the farmer of a high water table and an ample water supply should never be forgotten. Further, a marsh can raise a valuable crop of fur, sometimes worth more in dollars than any crcp it could produce after being drained. The present dry spell can at least remind us to preserve those marshes that still remain.

EDITOR'S NOTE: The figure of $40 \%$ for the Canvasback and Redhead kill, arrived at by Dr. Hcuston on the basis of his bandin: returns, coincides almost exactly with the findings of the United States Fish and Wildlife Service whose records show that hunters take an astonishing $47 \%$ of the Canvasback population each fall. Even more sobering are the statistics released by $H$. Albert Hochbaum, director of the Delta Waterfowl Research Station (Winnipeg Free Press, Sept. 24, 1958). Dr. Hochbaum told the executive of the Manitoba Federation of Game and Fish Associations that banding returns indicate that $90 \%$ of the banded adult female and young Canvasbacks flying south are killed by U.S. and Canadian hunters annually. This removes any chance of natural increase among the Canvasbacks because it is a known fact that when the kill is greater than $15 \%$ natural increase ceases in any species.

The estimated Canvasback population in North America, according to Dr. Hochbaum, is now 350,000 . This low figure sinks when the sex ratio is examined. There are 70 males for every 30 females, reducing the reproduction stock to about 100,000 breeding pairs. The sex ratio is, aggravated by the fact that males go to the northern lakes following the breeding season and later, when they go south, avoid the hunting marshes of southern Canada and the United States where female Canvasbacks are subjected to heavy hunting pressure.

\title{
PRELIMINARY REPORT ON THE PRAIRIE NEST RECORDS SCHEME
}

\section{By E. L. Fox, Regina}

The Prairie Nest Records Scheme which began in the spring of this year had by the middle of October received over 600 returns on 91 species of birds. We know that there are a number of cards still to be turned in and we should like to have these as quickly as possible in order that they may be included in the first annual report to be published in the March issue of the Blue Jay.

We have received cards from many areas in the scuthern half of Saskatchewan and in addition we have a few returns from Alberta and Manitoba. It is important that our Alberta and Manitcba members send in returns as the Prairie Nest Records Scheme is intended to bridge the gap between Ontario and British Columbia where similar information is being recorded.

Returns have been received on 91 species including most of the common birds. Strangely enough, reports have not yet been received for the following common species: Greenwinged Teal, Redhead, Gray Partridge, Willet, Franklin's Gull, Bonaparte's Gull, Burrowing Owl, Brown Thrasher, Baltimore Oriole. On the other hand, nesting information has been received for a number of species which are rare or whose nests 
are difficult to find. These include: Bald Eagle, Prairie Falcon, Sora, Common S ni p e, Upland Plover, Veery, Ovenbird, Bobolink, Rosebreasted Grosbeak.

During the past nesting season a number of inquiries have been received on various aspects of the scheme. The most frequent question asked is, "How can a single observation of a common nesting bird contribute anything of value to a Nest Records Scheme?" Several points should be made in answering this question:

(1) It is important that the observation be recorded and thus made available to other observers rather than lying buried in a field note book.

(2) The observation may establish a breeding record for your district.

(3) The observation may establish a breeding date for your district.

(4) The observation may give additional information abcut the breeding range of a certain species. For example, records submitted from observers in Saskatchewan may well help to determine the breeding status and range of the Western Kingbird. The Western Kingbird nests in Regina. It does not nest in Prince Albert, as far as I know. Somewhere between these two cities is the northern breeding range for Saskatchewan of the Western Kingbird. Nest record cards could determine the northern range of this bird.

(5) The bird considered common by one observer may actually not be common in another district.

A nest record card fully completed is, of course, most desirable. If these cards are received in sufficient numbers we shall have a file of information that may well pose many questions for the professional ornithologist to answer. The important thing is that only by the concerted effort of members submitting cards can this fund of information be made available as a basis for further investigation. Please send your cards immediately to Prairie Nest Records Scheme, c/o Saskatchewan Museum of Natural History, Regina, Sask.

\section{INFORMATION NEEDED ON CLAY-COLORED SPARROW (Spizella pallida)}

An appeal has been made for information about the Clay-colored Spiarrow by Oscar M. Root who is preparing a life history of this sparfor for the Smithsonian Institution (Bent series). As the s e c o nd volume of the Fringillidae will not go to press for several years, it will be possible to use material submitted within the next two or three years or more.

Infcrmation is needed on the following topics:

1. Behaviour-Root has very little information on courtship behaviour. He asks specifically: Do males arrive on breeding grounds before females? Are birds "paired" when they arrive? What is the size of territory? What is typical territorial $b=-$ haviour? Besides courtship behaviour, information on unusual behaviour at any time would be useful.

2. Voice-At how many yiards can song be heard? Does male ever sing on nest? during flight? Do only males sing? Height at which male sings? Does the Clay-color sing and feed in about the same place? Does it ever sing after the young leave nest?
3. Migration - Information needed on behaviour during spring and fall migration. Does the Clay-color migrate by day or by night?

4. Nesting-Positive proof (banding, etc.) needed of number of broods per season. General description wanted of newly-hatched Claycolor, nest-building, etc. Which bird builds the nest? How far do they travel for food? What care is given young after leaving the nest? How many eggs? Period of incubation?

5. Enemies- What enemies other than Cowbirds?

6. Parasites-Any information on internal or external parasites, or nest parasites.

7. Any records of lalbinism or melanism in Clay-color?

8. Any evidence of westward movement of species?

Anyone who now has this kind of information, or is in a position to make a study of this common Saskatchewan sparrow over the next year or so, should write for the detailed list of specific information needed, to Oscar IM. Root, Brooks School, North Andover, Mass., U.S.A. 